\title{
Promoting food security by supporting Agricultural R \& D
}

\author{
J.D. MULLEN \\ Charles Sturt University, Wagga Wagga, New South Wales
}

\begin{abstract}
Productivity gains are an important source of wealth in any economy. Productivity growth in the agriculture sectors in Australia and New Zealand has been credible relative to other sectors of their economies. However, at least for Australian broadacre agriculture, productivity growth has slowed in the last decade and this has been particularly true for cropping specialists. Part of the slowdown can be attributed to the run of bad seasons over the last decade but recent econometric analysis confirms that stagnant investment in agricultural R \& $\mathrm{D}$ has also played a part in this slowdown. Trends in public investment in agricultural R \& D are reviewed. Evidence of the continuing high returns to agricultural $\mathrm{R} \& \mathrm{D}$ is also reviewed. However, there remains scepticism about whether investment in agricultural $\mathrm{R}$ $\& \mathrm{D}$ is a good use of public funds. It is important that stakeholders in agricultural R \& D be able to present credible evidence of the impact of R \& D both on industry and the community at large and be able to cogently argue for continued public funding. The consequences of any slowdown in agricultural productivity in rich countries associated with a slowdown in public investment in R \& D are likely to be a slowdown in the "spillover" of technology to poor countries and perhaps food security issues related to rising food prices. The need to adapt to climate change and feed 3 billion more people exacerbates these challenges.
\end{abstract}

Keywords: productivity, returns to research, food security

\section{Introduction}

There has been slow growth in public investment in agricultural $\mathrm{R} \& \mathrm{D}$ in rich countries in recent decades (Pardey et al. 2006). Recently evidence is also emerging of a slowdown in productivity growth in agriculture in at least some rich countries. Agricultural

Figure 1 Trends in multifactor productivity and the terms of trade for Australian broadacre agriculture.

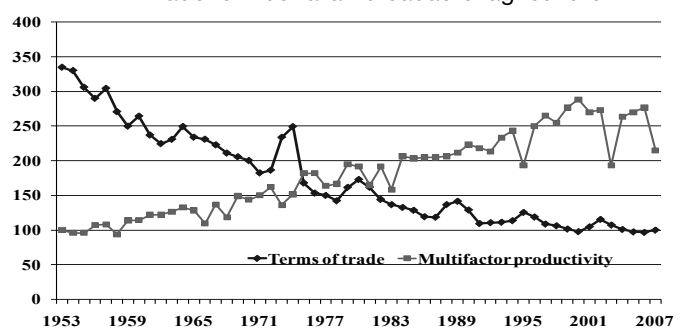

R \& D can be thought of as adding to a knowledge stock that has an impact on productivity for 35 or more years. It is probable that the consequence of a slowdown in $\mathrm{R} \& \mathrm{D}$ investment is now beginning to become evident in slower productivity growth. New technologies developed in rich countries "spill over" to poor countries and hence slower productivity growth in rich countries gives rise to concern about food security in terms of rising prices for food in poor countries. This rise in food prices may occur directly through slowly growing production and indirectly through less technology "spillovers". The need to adapt to climate change and feed 3 billion more people exacerbates these challenges. In this paper, trends in productivity and in public R \& D investment in Australia and New Zealand are reviewed, as is evidence pointing to continued high returns to R \& D. Some reasons are advanced as to why there remains scepticism about the returns to agricultural research and suggestions are put forward as to how this scepticism might be countered.

\section{Productivity growth in Australian broadacre agriculture}

The estimates of productivity growth in Australian broadacre agriculture used here were based on farm survey data from the Australian Bureau of Agricultural and Resource Economics (ABARE). A more thorough review of the trend in agricultural productivity in Australia and its estimation can be found in Mullen (2010b). Productivity growth is measured as the growth in outputs less the growth in inputs ${ }^{1}$. Starting from 100 back to $1952-1953$, the estimated multifactor (MFP) index increased to 218.3 in 2006-2007 with the annual growth rate of $2.0 \%$ a year (Fig. 1). The index is highly variable, falling in 20 of the 55 years, reflecting seasonal conditions. Such variability makes it difficult to discern trends in the underlying, more stable rate of technological change.

Changes in productivity can be compared with changes in the terms of trade faced by farmers ${ }^{2}$ as a

\begin{tabular}{lrrrrr} 
Table 1 & $\begin{array}{l}\text { Productivity } \\
\text { broadacre agriculture. }\end{array}$ \\
\multicolumn{7}{c}{ growth in sectors of } & Australian \\
\hline \multicolumn{7}{c}{ All broadacre } & Cropping & $\begin{array}{r}\text { Mixed crop } \\
\text {-livestock }\end{array}$ & Beef & Sheep \\
\hline $1979-80$ to $1988-89$ & $2.2 \%$ & $4.8 \%$ & $2.9 \%$ & $-0.9 \%$ & $0.4 \%$ \\
$1984-85$ to $1993-94$ & $1.8 \%$ & $4.7 \%$ & $3.2 \%$ & $3.1 \%$ & $-1.7 \%$ \\
$1988-89$ to $1997-98$ & $2.0 \%$ & $1.9 \%$ & $1.4 \%$ & $1.6 \%$ & $-1.2 \%$ \\
$1993-94$ to $2002-03$ & $0.7 \%$ & $-1.2 \%$ & $0.0 \%$ & $1.0 \%$ & $3.4 \%$ \\
$1997-98$ to $2006-07$ & $-1.4 \%$ & $-2.1 \%$ & $-1.9 \%$ & $2.8 \%$ & $0.5 \%$ \\
$1977-78$ to $2006-07$ & $1.5 \%$ & $2.1 \%$ & $1.5 \%$ & $1.5 \%$ & $0.3 \%$ \\
\hline
\end{tabular}


Figure 2 Real public investment in agricultural $R$ \& $D$ in Australia.

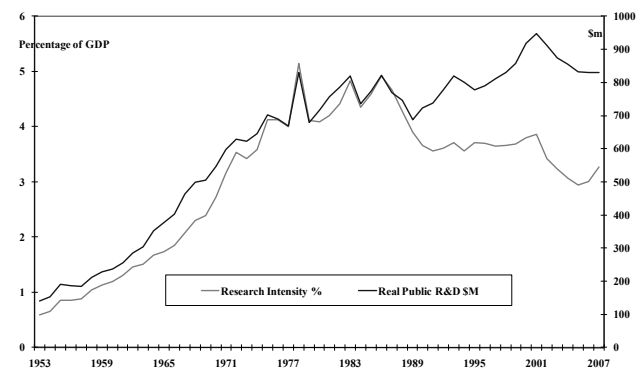

partial indicator of whether Australian agriculture is becoming more or less competitive. The conventional wisdom is that the terms of trade facing Australian agriculture have been declining inexorably. The real situation was a decline of $2.6 \%$ per annum from 1953 to 1990, and less than $1 \%$ per annum from 1991 to 2007.

A better indication of "competitiveness" is the growth in productivity in agriculture relative to that in the rest of the economy. Mullen (2010b) reported ABS data suggesting that in recent decades productivity in the agriculture, fisheries and forestry sector often grew at three times the rate of that in the rest of the economy ${ }^{3}$. The agricultural sectors in few other OECD countries have performed as well. Hence, productivity growth in the Australian agricultural sector has likely been strong enough to enhance the sector's competitiveness relative to other sectors of the economy and relative to the agricultural sectors in many other countries.

The ABARE broadacre dataset can be stratified to provide estimates of productivity growth by the enterprise or industry: cropping, mixed crop-livestock, beef, and sheep. Since 1978, cropping specialists have achieved much higher rates of MFP growth $(2.1 \%$ per year) than have beef specialists $(1.5 \%$ per year $)$ and sheep specialists $(0.3 \%$ per year) (Table 1$)$ (Nossal et al. 2009). Generally output grew while input use stayed static or declined. In particular, cropping specialists greatly increased their use of purchased inputs $(4 \%$ per year) and reduced their use of labour $(-0.2 \%$ per year) and capital ( $-0.4 \%$ per year). A switch toward reducedtillage cropping - which is also associated with more diverse cropping rotations and more opportunistic cropping to exploit available soil moisture (as opposed to fixed rotations and fallows) - partly explains the changes in input use and the strong rate of productivity growth.

However, recent data suggest that productivity growth in Australian agriculture - and that of other developed countries (Pardey et al. 2006) - has slowed in the 10 years leading up to 2007. The growth rate from 1998 to 2007 fell at the rate of $-1.4 \%$ (Table 1). Trends in productivity have not been even across industries within broadacre agriculture (Table 1). For cropping specialists, MFP grew by $4.8 \%$ per year from 1980 to 1994 but declined by $2.1 \%$ per year from 1998 to 2007. There seems much less evidence of a slowing in MFP growth for beef and sheep specialists. Nossal et al. (2009) speculated that productivity growth of sheep specialists, usually ranking the lowest among the industry groups, might finally be catching up.

Why might broadacre productivity be slowing? Some argue that it is not surprising that productivity growth in agriculture is drifting down because "all the big gains have been made." However, Australian research agronomists seem confident that there are still practical research opportunities to develop new technologies that would allow farmers to grow crops more efficiently. Anderson \& Angus (World Wheat Book, In Press) said: "Despite the new technology, the mean yield is only 2.0 tonnes per ha, about half of the water-limited potential.... Further research will be needed to increase yield closer to the water-limited potential. The gains are most likely to come from tactics that enable crops to take advantage of the more favorable seasons in the variable climate, and concentration of inputs on the parts of farms with the highest yield potential."

Two other factors likely to explain a significant portion of productivity growth in broadacre agriculture (at least at the aggregate level) are climate or seasonal conditions and public investment in agricultural research. No doubt some of the recent productivity decline is due to the run of poor seasons shown by a rainfall anomaly ${ }^{4}$ for the Murray Darling Basin from 2000-2008, but recent research by Sheng et al. (2010) has demonstrated that the stagnation in public investment in R \& D from the late 70 s is now starting to contribute to the slowdown in MFP.

\section{Productivity growth in New Zealand agriculture}

There have been a number of studies of productivity growth for the New Zealand economy and its agriculture sector (reviewed in Mullen (2010b)). Attention here is confined to the work of Hall \& Scobie (2006), because of its longer historical perspective, and the most recent measure of MFP in New Zealand agriculture published by Statistics New Zealand ${ }^{5}$. Both studies used valueadded measures of MFP, and MFP growth was estimated as a compound annual growth rate. Hall \& Scobie (2006) estimated that, over the entire period 19272001 , MFP grew at a rate of $1.8 \%$ per year. The average annual growth rates by sub-period were $1.0 \%$ (19271956), $2.2 \%(1957-1983)$, and $2.6 \%(1984-2001)^{6}$. It is noteworthy that this period of accelerating MFP from 1984 coincides with a period of major economic reform within the New Zealand economy. Statistics New 
Zealand publishes a series for the years 1978 to 2008 . Hall \& Scobie have not updated their series, and the two series are unlikely to be perfectly consistent. Statistics New Zealand estimated that MFP in agriculture (not including forestry and fisheries) grew at a rate of 3.4\% per year, 3 times faster than MFP growth of $1.1 \%$ per year for the market economy. Unlike Australia, there is little evidence that growth in productivity in New Zealand agriculture has slowed although no formal analysis has been undertaken.

Using different measures Hall \& Scobie (2006) and Cao \& Forbes (2007) compared productivity trends with trends in the terms of trade. The Hall \& Scobie (2006) series declined from around 176 in 1953 to 100 in 2004. This is a much slower rate of decline than that faced by Australian farmers. Both studies suggest that there has been no trend in the terms of trade for the New Zealand farm sector since the late 1980s, similar to the experience of Australian farmers. As a consequence, the gains to New Zealand farmers from productivity growth were not offset by unfavorable price changes to the same extent as for Australian farmers although in recent times their experiences are similar.

It is not easy to compare rates of productivity growth between New Zealand and Australia because of difference in methods, time periods etc. However, the most recent multilateral study by Rao et al. (2004) found that MFP growth rates in Australia and New Zealand over the period 1970-2001 were $2.0 \%$ and $0.8 \%$ per year, respectively. In addition, given that earlier analyses had suggested that MFP growth in New Zealand agriculture had not been as fast relative to the New Zealand market economy as had been the case in Australia, Mullen et al. (2008) had concluded that it was likely that Australian agriculture may have become more competitive than New Zealand agriculture in the 90s. The recent estimates of MFP growth in NZ cast doubt on this conclusion. Moreover, the slowdown in productivity growth in Australia since 2000 is likely to have halted that process at least temporarily.

\section{Trends in public investment in agriculture in Australia and New Zealand}

New Zealand and Australia are similar in the importance of the public sector to agricultural research investment. In both, the public sector provides more than $80 \%$ of funds (including industry levies), which is much higher than in other developed countries. However, public research intensity in New Zealand at about $2.0 \%$ is low relative to other developed countries $(2.6 \%)$ and relative to Australia ( $3 \%$ in recent years).

\section{New Zealand}

Public investment in agriculture, fisheries and forestry
(AFF) R \& D grew steadily until the late 60 s, at which time there was a surge in investment, until the mid 70s. From the mid 70 s to the mid 90 s there was little change in the annual level of public investment in real terms (Mullen et al. (2008) using Hall \& Scobie (2006) data). According to MORST data (2006) public investment in $\mathrm{R} \& \mathrm{D}$ in the agriculture, forestry and fisheries sector (directed to this socio economic objective) in New Zealand increased slowly from $\$ 174 \mathrm{~m}$ in 1994 to $\$ 182 \mathrm{~m}$ in 2004 (where investment is expressed in 2004\$s using a CPI based in 2004). Private investment increased more quickly over this period from $\$ 34 \mathrm{~m}$ to $\$ 126 \mathrm{~m}^{7}$. New Zealand's level of public AFF R \& D spending as a percentage of AFF GDP, research intensity, was about $2.5 \%$ in 1994 but has drifted down to about $2.0 \%$ in 2004 as the growth in GDP outpaced the growth in public R \& D investment ${ }^{8}$.

\section{Australia}

The way in which the data on $\mathrm{R} \& \mathrm{D}$ investment have been assembled from ABS sources and from a previous dataset developed by Mullen et al. (1996) is described in Mullen (2007). Expenditure is attributed to research providers, rather than funders. As a result, expenditure by state departments of agriculture or universities, for example, includes funds obtained from rural RDCs. Attention is focussed on farm production research and investment in R \& D in fisheries and forestry and in the processing of farm products is not included (unlike the New Zealand data above for the AFF sector). The GDP deflator was used to express investment in R \& D in 2008 dollars. Total public expenditure on agricultural $\mathrm{R} \& \mathrm{D}$ in Australia has grown from A $\$ 140$ million in 1952-1953 to almost A $\$ 830$ million in 2006-2007 (in 2008 dollars) (Fig. 2) (Mullen 2010a). Expenditure growth was strong to the mid-1970s but has essentially been static since that time although there was a spike in investment (nearly A\$950 million) in 2001. Likewise, agricultural research intensity, which measures the investment in agricultural R \& D as a percentage of GDP, grew strongly in the 1950s and 1960 s, but has been drifting down from about 4.0-5.0 \% annually of agriculture GDP in the period between 1978 and 1986 to about $3.0 \%$ per annum in recent years (as compared to $2.4 \%$ per annum in developed countries). So public research intensity has been much higher in Australia than in New Zealand. Mullen et al. (2008) suggested that while public research intensity in Australia has been about twice that in New Zealand, returns to agricultural research in the two countries seemed similar, and hence relative levels of research investment seemed appropriate. Australia's better performance may arise because it has a larger agricultural sector and larger share of broadacre cropping (where MFP growth was 
most rapid, at least until 2000).

A feature of the agricultural research sector in Australia has been the prominent role played by the research and development corporation (RDCs). In approximate terms, RDCs commission agricultural research on a competitive basis amongst public and private research providers using funds from levies on production and matching Commonwealth grants (up to $0.5 \%$ of the value of production). The attraction of the $\mathrm{RDC}$ system is that it ameliorates the non-excludability characteristic of information generated by research, while preserving the benefits from its non-rival nature. In 2007 , total expenditure by the RDCs on production agricultural research (excluding the fisheries, forestry and energy RDCs and LWA) was A $\$ 478$ million (\$2008), which is almost $60 \%$ of total public expenditure on agricultural $\mathrm{R} \& \mathrm{D}$. Some of this investment by the RDCs is directed towards the processing sectors rather than production agriculture and some is directed to environmental outcomes. If these investments outside production agriculture amount to a third of the total then it seems likely that the RDCs are funding $40-50 \%$ of research into production agriculture in Australia. Recall also that over half of these RDC funds are raised from farmers. In the $1980 \mathrm{~s}, \mathrm{RDC}$ funding amounted to less than $15 \%$ of total public expenditure on agricultural $\mathrm{R}$ \& D.

\section{Public R \& D investment causes productivity growth in agriculture in Australia and New Zealand}

Economists have used three broad approaches to estimating the returns from investments in agricultural $\mathrm{R} \& \mathrm{D}$. One approach has been to econometrically estimate a relationship between agricultural productivity growth and public $\mathrm{R} \& \mathrm{D}$ investment. New Zealand studies of this nature are reviewed in Hall \& Scobie (2006). In an earlier study, Scobie \& Eveleens (1987) using data from 1926 to 1984, found that research contributed significantly to the growth of productivity over an extended period of 23 years on average, generating a real rate of return of $30 \%$ per year. Hall \& Scobie (2006), using data from 1926 to 2001, found that foreign research was a significant variable in explaining MFP in New Zealand agriculture. However, the impact of domestic research was not stable across alternative specifications. Their "preferred" model, based on significant contributions to productivity of both foreign and domestic stocks of knowledge, yielded a rate of return of $17 \%$ p.a. to investment in domestic R \& D. Hall \& Scobie concluded that while foreign investment in research was likely to have a significant impact on productivity growth in a small open economy like New Zealand, it was also highly probable that a domestic research sector was required to identify relevant foreign knowledge and adapt it to the New Zealand environment, despite the difficulties encountered in precisely estimating the contribution of domestic investment in research.

The econometric work in Australia has been reported in papers which I have co-authored (Mullen, 2007, for example). The general approach was to regress productivity growth in broadacre agriculture against explanatory variables including domestic research and extension knowledge stocks, farmers' education, weather and the terms of trade. Lags of 16 and 35 years were used to assess R \& D impacts on TFP. Mullen \& Cox suggested that the returns to research in Australian broadacre agriculture were in the range of $15-40 \%$ and more recent analyses tell a similar story. The Australian data are being updated in cooperative work with ABARE for submission to the current Productivity Commission enquiry into the funding of agricultural R \& D in Australia (www.pc.gov.au/projects/inquiry/ rural-research). Note that these econometric analyses make no attempt to account for environmental and community "spillovers" from agricultural R \& D.

A second approach is to decompose productivity growth by the contributions from domestic and foreign $\mathrm{R} \& \mathrm{D}$ and other sources of growth as detailed in Mullen et al. (2006). They assessed that for Australian broadacre agriculture, decomposing MFP growth of $2.5 \%$ into $1.2 \%$ from domestic $\mathrm{R} \& \mathrm{D}, 0.8 \%$ from foreign $\mathrm{R} \& \mathrm{D}$ and $0.5 \%$ from other sources of growth and then relating these benefits to investment in domestic R \& D gave internal rates of return of $17-21 \%$. Similarly for New Zealand agriculture, productivity growth of $1.8 \%$ came from domestic $\mathrm{R} \& \mathrm{D}$ and extension $(0.7 \%)$, foreign $\mathrm{R} \& \mathrm{D}(0.7 \%)$ and other sources such as infrastructure and education $(0.4 \%)$ gave internal rates of return of 14 $-18 \%$. In both cases any benefits beyond 2001 were not accounted for. Recall, that for both countries measures of MFP growth have since been revised.

The third broad approach has been to measure the benefit costs ratio (BCR) of individual research projects or of portfolios of projects. There is a growing body of analyses using measures of economic surplus in a benefit cost framework to assess the impact of new technologies developed through research. These analyses have been funded by both research providers, State Departments of Agriculture for example, and research funders, the RDCs for example. Some have been conducted in-house and some by external consultants.

I (Mullen (2004), and extended in later seminars) reported that the average $\mathrm{BCR}$ for 10 large projects evaluated by NSW DPI economists in 2003 and 2004 was 11.2:1 (ranging from 2 to 66:1). DAF (2001) 
reported that Chudleigh \& Simpson (2001) had found that the average BCR for a sample of projects across several of the RDCs was 7:1. Goucher (Council of the Rural Research and Development Corporations, 2010) in reviewing the PC (2007) report into Public Support for Science and Innovation identified 41 benefit cost analyses for rural $\mathrm{R} \& \mathrm{D}$ projects spanning a broad array of industries and types of research. A simple average of these results shows a BCR of 68.5. He also summarised evaluations commissioned by the Council of the RDCs in 2008 and 2009. He found that when benefits (excluding unpriced environmental benefits) were estimated over 25 years, the average BCR was about 11:1 for about 90 randomly selected projects.

Goucher also reviewed the study by Alston et al. (2000) of rates of return analyses worldwide. Alston et al. found that the average of the estimates of the rate of return to research only (from 1144 studies) was $100 \%$ per annum. The range was wide, but less than 10 estimates (less than 1\%) found a negative rate of return. Goucher summarised the findings from the 154 Australian and New Zealand studies reviewed by Alston et al. The average estimated rate of return from these studies was $87 \%$ p.a. I am less familiar with the extent of impact assessment and benefit cost analysis of R \& D in New Zealand. I have become aware of a series of impact assessment studies undertaken by Lovatt (AgResearch) for MORST. While the range of studies is extensive, most of these studies stop short of a arriving at an estimate of benefits and costs, presumably because of resource limitations. However, it is likely that some areas of rural R \& D investment will have earned high returns.

The broad conclusion from this substantial body of economic analysis of investment in publicly funded agricultural R \& D both globally and in Australia and New Zealand is that returns are very high and this suggests that there may be a degree of under-investment in agricultural research in Australia and New Zealand as well as globally.

\section{Why support for public investment in agricultural $\mathbf{R} \& \mathbf{D}$ might be weak}

Several considerations may help to explain this seemingly anomalous situation where there has been declining public investment in agricultural R \& D over a period of decades and a more recent slowdown in productivity growth, at least in Australia, while rates of return to investment have remained high.

1. Despite the evidence presented above, many, including farmers, have difficulty discerning the benefits from new technology and hence may be lukewarm in their support for R \& D levies (Kerin 2010). Part of this scepticism may arise from the long $\mathrm{R} \& \mathrm{D}$ lags, from long-term biological and weather variation and because benefits of a new disembodied technology, applying to a farming system rather than individual commodity, may be both risky and not obvious. The benefits may not be evenly distributed between farmers.

2. Perhaps the long lags between investment in $\mathrm{R} \& \mathrm{D}$ and improved productivity are not appreciated so that the consequences of a neglect of investment in $\mathrm{R} \& \mathrm{D}$ in both countries are only just beginning to emerge. More cynically perhaps the misalignment of the lengths of $\mathrm{R}$ $\& \mathrm{D}$ and political cycles is not conducive to the maintenance of research capacity.

3. There is widespread scepticism about estimates of very high rates of return to agricultural $\mathrm{R}$ \& D. Empirically establishing a clear causal relationship between investment in $R$ \& $D$ and productivity gains is difficult at least in part because of the uncertainty surrounding the counterfactual of how the industry would develop in the absence of the R \& D investment. This problem arises both in aggregate analyses of returns to research, where it is compounded by a host of econometric issues, but also at a project level where "with" and "without project" scenarios have to be carefully identified. More often than not, analyses where implausible rates of return are estimated can be reasonably criticised on these grounds. Such "window dressing" exercises engender scepticism about the whole literature.

4. There are some naive and fallacious views about the role of government amongst both purchaser and providers of agricultural research. Some funders have a narrower view about the extent of market failure and hence the need for government intervention than formerly especially with the evolution of schemes facilitating farmers acting collectively to fund $\mathrm{R} \& \mathrm{D}$. The naive view here is that industry (i.e. RDCs) should fund R \& D delivering benefits to industry and government should fund $\mathrm{R} \& \mathrm{D}$ delivering benefits to the broader community. This view is naive because (a) applied agricultural research delivers a mix of public and industry goods. Because there is usually little information about the size of the industry benefits relative to community benefits, there is great subjectivity in assessing even whether projects deliver predominantly industry benefits or predominantly public benefits, and (b) the present arrangement where typically a common levy is imposed across the industry means that while the public good characteristics 
of R \& D - non-excludability and non-rivalry are ameliorated they are not eliminated. Industry does not have the incentive or the mechanism to fully reveal its willingness to pay for research services and hence from the perspective of both the industry and the community, underinvestment remains a problem (Alston pers. comm.).

Turning to research providers, they sometimes have fallacious views about what is meant by a public good and hence their arguments for public funding are too easily countered by funders. The industry benefits of research are those shared by producers, processors and consumers in the form of lower production and processing costs, lower retail prices, reduced wastage and improved quality. Lower consumer prices, increased exports and increased employment in rural communities are examples of benefits, sometimes fallaciously claimed as public benefits, which are already included in industry benefits. Public goods on the other hand, come in the form of better human and environmental health outcomes, gains in social capital and in scientific capacity, reduced biosecurity risks, "spillovers" of technology to poor countries etc. No market transaction is usually involved in enjoying these public good benefits.

\section{What is to be done to maintain investment in $\mathbf{R} \& \mathbf{D}$ ?}

In my view a key weapon in maintaining investment in agricultural $\mathrm{R} \& \mathrm{D}$, whether by the public sector or industry, is a commitment to assessing its impact so that stakeholders are better informed about the benefits and costs. Such a sustained culture of impact assessment would include being able to put forward a sound rationale for government investment in terms of addressing a clearly specified case where the community's expectations are not being met, a well defined market failure in other words. Fewer rigorous assessments would engender less scepticism than a multitude of "window dressing" exercises.

Organisations with a strong commitment to impact assessment include ACIAR and the Council of the RDCs. The State Departments of Agriculture and individual RDCs wax and wane in their enthusiasm for impact assessment. There has been a strong focus on ex post assessments with the main objective of meeting accountability standards required or expected by stakeholders such as Federal and State Treasuries. The focus of most of these studies has been on estimating industry benefits in the form of reduced production and processing cost, higher yields, lower wastage and improved quality. In the future more needs to be done in valuing benefits to the community in the form of better environmental, human health and resource management outcomes developed by agricultural R \& D. In particular the changes in environmental resource flows from changes in land use should be better quantified and priced. At present while industry benefits are routinely quantified, these community benefits are most often only identified qualitatively and the question of how the funding of such research is shared is most uncertain. The focus on meeting accountability requirements "short-changes" the potential benefits likely to flow from an improved culture of impact assessment. First there is much to be learnt by scientists and economists about the characteristics leading to high impact research from regular participation in impact assessment processes. Second, impact assessment processes can be used to guide the allocation of scarce research resources although much remains to be done to develop process that can be applied in a timely, cost effective manner.

\section{Concluding comments}

Productivity growth in agriculture in Australia and New Zealand has been strong in recent decades relative to both the terms of trade and productivity growth in the rest of the Australian and New Zealand economies. However, in Australia, broadacre productivity growth has slowed since 2000. There seems little indication yet of this in New Zealand but otther OECD countries seem to be experiencing this slow down. For Australian broadacre agriculture while some of this slow down can be attributed to an unusually long run of bad seasons, some can also be attributed to the stagnation in public investment in agricultural R \& D. In both Australia and New Zealand the growth in public investment in agricultural R \& D has been slow in dollar terms and has actually declined in research intensity terms relative to the size of the respective agricultural sectors. This decline in public investment has occurred despite ongoing strong evidence that the returns to public investment in $\mathrm{R} \& \mathrm{D}$ in both countries are high and show no signs of declining. Given the long lags of 35 years or more over which $\mathrm{R} \& \mathrm{D}$ has an impact on productivity, it seems likely that, at least for Australian broadacre agriculture, the consequences of this stagnation in public investment are starting to emerge.

These consequences flow beyond Australia and New Zealand. If productivity is slowing in rich countries because of less public investment in R \& D then food security issues, particularly in terms of rising food prices, may develop in poor countries dependent to a significant degree on rich countries for new agricultural technologies. Adapting to climate change and meeting the needs of 3 billion more people add to the challenge. The public agricultural R \& D sector needs to develop a strong culture of impact assessment so as to be able to demonstrate the outcomes from research for farmers, 
processors and consumers and for the community in terms of environmental and human health outcomes and the maintenance of scientific capacity. These outcomes must be demonstrated in a rigorous manner eschewing "window dressing" exercises that engender scepticism and with a clear understanding of the role of government in funding R \& D.

\section{REFERENCES}

Alston, J.; Andersen, M.; James, J.; Pardey, P. 2010. Persistence Pays: US Agricultural Productivity Growth and the Benefits from Public R\&D Spending, Springer, New York.

Alston, J.M.; Chan-Kang, C.; Marra, M.C.; Pardey, P.G.; Wyatt, T.J. 2000. A meta-analysis of rates of return to agricultural R\&D: ex pede herculem? Research Report No. 113, International Food Policy Research Institute, Washington D.C.

Anderson, W.K.; Angus, J.F. 2010. Agronomy and Cropping Practices in Semi-Arid Conditions in Australia. Eds. Bonjean, A.; Angus, W.; van Ginkel, M. World Wheat Book 2, Limagrain (In Press).

Cao, K.; Forbes, R. 2007. Productivity in the New Zealand Primary and Downstream Sectors. Australasian Agribusiness Review, 15 (Paper 9).

Chudleigh, P.; Simpson, S. 2001. Report on the performance of rural research and development corporations and options for future performance measures of rural research and development corporations. Agtrans Research, Brisbane, Australia.

Council of the Rural Research and Development Corporations. 2010. Submission to the Productivity Commission enquiry into rural research and development corporations, available at PC enquiry website.

DAFF. 2001. Innovating rural Australia: research and development corporations outcomes. DAFF, Canberra, Australia.

Hall, J.; Scobie, G. 2006. The Role of R\&D in Productivity Growth: The Case of Agriculture in New Zealand: $1926-27$ to 2000-01. New Zealand Treasury Working Paper 06/01, Wellington.

Kerin, J. 2010. What policy framework would I now establish for agricultural research, development and extension, if I were still Minister for Agriculture, Fisheries and Forestry? Agricultural Science 22: 1724.

MORST. 2006. Research and development in New Zealand: A decade in review, MORST. Available at www.morst.govt.nz.

Mullen, J.D. (Ed.) 2004. Evaluations in 2003 of Five Areas of Investment by NSW Agriculture: Summary, Economic Research Report No. 22, NSW Department of Primary Industries, Orange.
Mullen, J.D. 2007. Productivity growth and the returns from public investment in $\mathrm{R} \& \mathrm{D}$ in Australian broadacre agriculture. Australian Journal of Agricultural and Resource Economics 51: 359-384.

Mullen, J.D.; Scobie, G.M.; Crean, J. 2008. Agricultural Research: Implications for Productivity in New Zealand and Australia. New Zealand Economic Papers 42: 191-211.

Mullen, J.D. 2010a. Trends in investment in agricultural R\&D in Australia and its potential contribution to productivity. Australasian Agribusiness Review 18, Paper 2, at http://www.agrifood.info/review.

Mullen, J.D. 2010b. Agricultural productivity growth in Australia and New Zealand. Chapter 5 In: Shifting Patterns of Agricultural Production and Productivity Worldwide. Eds. Alston, J.M.; Babcock, B.A.; Pardey, P.G. CARD-MATRIC Electronic Book. Ames, IA: Center for Agricultural and Rural Development, May 2010. Available at http://www.matric.iastate.edu/ shifting patterns/.

Nossal, K.; Zhao, Z.; Sheng, Y.; Gunasekera, D. 2009. Productivity movements in Australian agriculture. Australian Commodities 16: 206-216.

Statistics New Zealand. 2010. Industry productivity statistics 1978-2008, available at:

http://www.stats.govt.nz/browse for stats/ economic indicators/productivity/industry-levelproductivity-1978-2008.aspx

Pardey, P.G.; Alston, J.M.; Piggott, R.R. Eds. 2006. Agricultural R\&D Policy in the developing world: too little, too late?, Washington D.C.: International Food Policy Research Institute.

Productivity Commission. 2007. Public Support for Science and Innovation, Research Report, Canberra.

Rao, P.; Coelli, T.; Alauddin, M. 2004. Agricultural productivity growth, employment and poverty in developing countries: 1970-2000. Employment Strategy Papers, Centre for Efficiency and Productivity Analysis (CEPA), School of Economics, University of Queensland, Brisbane.

Scobie, G.M.; Eveleens, W.M. 1987. The return to investment in agricultural research in New Zealand: 1926-27 to 1983-84, Research Report 1/87, Ministry of Agriculture and Fisheries, Wellington.

Zhao, S.; Sheng, Y.; Mullen, J.D. 2010. Has growth in productivity in Australian broadacre agriculture slowed?. Contributed paper, 54th Conference of the Australian Agricultural and Resource Economics Society, February 10-12, 2010, Adelaide. 
1 The terms multifactor productivity (MFP) and total factor productivity (TFP) are used equivalently. The former term recognises that in practice not all factors can be measured and included in the index.

2 Reported in ABARE 2008 and estimated as the ratio of an index of prices received by farmers to an index of prices paid by farmers.

3 Mullen (2010a, b) explained difference in the ABARE and ABS MFP series for Australia.

4 The anomaly is the annual deviation in rainfall from average annual rainfall between 1961 and 1990.

5 Cao \& Forbes (2007) from NZ MAF also published a recent analysis of NZ MFP growth using Statistics NZ data. Their estimates of MFP growth were about $0.5 \%$ lower than Statistics NZ estimates. These estimates have not been reconciled.

6 Mullen, Scobie, and Crean (2008) reported lower growth rates because they re-estimated them from a regression of the log of MFP against a constant and time trend.

7 I have not tried to reconcile the MORST estimates of public investment in agricultural R\&D with those used in Mullen et al. (2008) series which indicated a marked increase in R \& D in the late 90 s.

8 Again I was unable to reconcile the series on AFF GDP used in Mullen et al. (2008) with more recent data from Statistics NZ. 